\title{
The Influence of Celebrity Endorsement, Product Quality and Price on Purchase Interest of Kanzler Single Sausage Products
}

\author{
Evelyn Maurencia ${ }^{1}$, Hery Winoto $\mathbf{T j}^{\mathbf{2}^{*} \text {, Soegeng Wahyoedi }}{ }^{\mathbf{3}}$ \\ ${ }_{1,2,3}$ Center of Innovation in Applied Management and Behavioral Economy (CIAMBE), Krida Wacana \\ Christian University, Indonesia \\ Corresponding Author*: hery.winoto@ukrida.ac.id \\ Evelynmaurencia1999@gmail.com,swahyoedi@ukrida.ac.id
}

\section{Abstract}

At this time, technological advances are increasingly having a strong enough impact and if it can be utilized properly, this maximizes the results obtained from the existence of the technology itself. Especially in the act of marketing an item, using social media that has many users will make the product marketing process much easier. Supported by the current pandemic conditions that have made major changes in purchasing and selling product transactions, as well as a fairly high increase in internet users. Therefore, using social media that displays advertisers in the form of videos will be considered effective. For now, people are starting to be presented with various types of social media featuring videos such as Youtube, Snapchat, Instagram \& TikTok. According to research (OGUNSIJI, 2012) celebrity endorsement is a marketing tool created to show differentiation points between various brands and coverage in the market. Meanwhile, (Nelson \& Gloria, 2012) focuses celebrity support on a global perspective because this is a communication strategy that will create promotional actions for a product in the form of goods and services in society. The right choice should be made to choose a celebrity to endorse a brand, as celebrity endorsement can affect the image and productivity of an organization in positive or negative ways. With this research, it is hoped that entrepreneurs who want to market their products will be wiser and easier in choosing what kind of media are currently having a high appeal to consumers. In addition, readers will also be invited to see the benefits of the impact of celebrity endorsement, the quality of a product and how the price affects consumer purchase interest.
Keywords

celebrity endorsement; product quality, price; purchase interest

\section{Introduction}

At this time, activities to promote a product can be done with various media, either by using advertisements, Word of Mouth, or using social media. Efforts to promote these products are to generate purchase interest from consumers. The most important component prior to the buying and selling of a product is buying interest. Thus, entrepreneurs will try many things to increase consumer buying interest for the products they will offer in order to increase the chances of selling their products. Given the large number of social media users today, especially millennials, who make social media a necessity so that the act of promoting a product will be considered more effective.

TikTok is the application that occupies the first position as the most downloaded application at this time. This happens because in addition to the appearance of an attractive application, its easy use and many options for editing videos. 
SIASAT Journal of Social, Cultural and Political Studies, 6 (1) January 2021, 59-72

ISSN: 2721-7469 (Print), 2721-7450 (Online)

Evelyn Maurencia, Hery Winoto Tj, Soegeng Wahyoedi: The Influence of Celebrity Endorsement, Product Quality and Price on Purchase Interest of Kanzler Single Sausage Products https://siasatjournal.com/index.php/siasat

Kanzler sausage is a product issued by PT Macroprima Panganutama (Cimory Group) which is superior because it contains 4 times more meat than other types of sausage, without msg and without coloring. In addition, Kanzler sausages are also one of the most commonly purchased products in large quantities at convenience stores. This is because the marketing process is considered successful through Tiktok media.

Of course this is possible with celebrity endorsement as well as increasing the chances of increasing consumer buying interest. Celebrity endorsement is a figure that can have an impact in the form of an invitation or be used as an example in a behavior. The quality of the product itself also provides an illustration of how a seller is able to provide the best for the product he is selling, simply, if a seller sells the highest quality product, that means it gives the best to consumers. The price set for a product must be comparable to the benefits that can be provided by the product because if the wrong price is set there is a possibility that consumer purchases of products made by consumers will decrease.

\section{Review of Literatures}

\subsection{Celebrity Endorsement}

In deciding to use a product, of course the consumer will first search for the use of the product. Amitay et. al (2020) stated that in marketing activities, the use of celebrities in advertising must be evaluated using the VisCAP (presenter effect in advertising) model. In this case Royan (2004) also explains that the VisCAP model has three elements as follows:

a. Visibility. Visibility is a dimension of how popular a celebrity.

b. The credibility of a celebrity includes two things, namely the expertise and objectivity. Celebrity's knowledge of a product is closely related to his or her expertise, while objectivity refers to the ability to give a product customer trust. Credibility consists of the following attributes:

1. Expertise, level of knowledge or expertise possessed by celebrities in their field.

2. Objectivity, customer perceptions of reputation. The assessment given for an object must be factual and real.

3. Trust, the presenter's willingness to be honest in making a statement. The public considers the claims made by advertising only to increase sales; therefore, the role of a celebrity is necessary to be someone who is considered honest in giving their opinion.

c. Attraction. Attractiveness means receiving a message that depends on the attraction of the supporters. Supporters will be successful in changing opinions and through the attraction mechanism, namely to arouse the feeling that the celebrity has something people want to have, so that they are willing to follow the message.

\subsection{Product Quality}

Product quality is a description of how a product is assessed, both from the material of manufacture, the product's shelf-life and the product's usefulness for its users.

According to (Tjiptono, 2008) in Retnowulan (2019) there are several dimensions of product quality, namely:

a. The performance of a product is closely related to its functional aspects in the form of characteristics that are considered by consumers in buying products.

b. The characteristics of the product which are aspects of excellence are used to increase its function, related to various product choices and their development.

c. Reliability is related to the success of the product in carrying out its role with a certain period of time and under certain conditions. 
d. The suitability of the product has a relationship with the suitability of the explanation that has been made based on what the consumer wants.

e. In Product Durability, there is a picture of economic age which consists of measuring the durability or the useful life of the product.

f. Quality can be perceived with a buyer description of the quality and superiority of a product.

g. In aesthetics is the appeal of the product to one's vision. This is related to how the product looks itself.

h. On the ability to serve in the form of speed, competence, ease, handling complaints that can satisfy consumers.

\subsection{Price}

Price is a very important component because it is a very sensitive part, both for sellers, especially buyers.

To help see how important indicators affect prices (Kotler and Armstrong, 2008), explains in their book that there are 4 indicators that should be considered:

a. On affordability, the set price can adjust so that it is affordable with the purchasing power of consumers.

b. On the suitability of a price with a quality product, it is necessary to set the price in proportion to the quality of the product.

c. In terms of price competitiveness, it is determined that it can compete with other products.

d. At the price conformity with the benefits must be proportional to the benefits provided to consumers.

\subsection{Purchase Interest}

In his research, (Assael, 2001) quoted by Mubarok (2016) explains that "Purchase interest is the tendency of consumers to buy a brand or take action related to purchases as measured by the level of consumers' likelihood of making a purchase" in addition to that in Putra's research (2017) also adding buying interest is obtained from the existence of a learning process and a thought process that forms a perception.

Sutisna (2003) in Listyawati (2016) explains that buying interest has several indicators, namely:

a. In transactional interest, is the possibility of consumers to buy products.

b. In Reference Interests, it is the possibility of consumers recommending products to others.

c. Preferential interest is an interest that reflects the behavior of someone who has the main choice for the product.

d. Explorative interest can describe the behavior of a person who is always looking for information about the desired product and looking for information to support the positive characteristics of a product.

\subsection{Hypothesis Development}

H1: Celebrity endorsement has an effect on buying interest in Kanzler sausage products

H2: Product quality affects purchase intention

H3: Price affects the interest in buying Kanzler sausage products. 


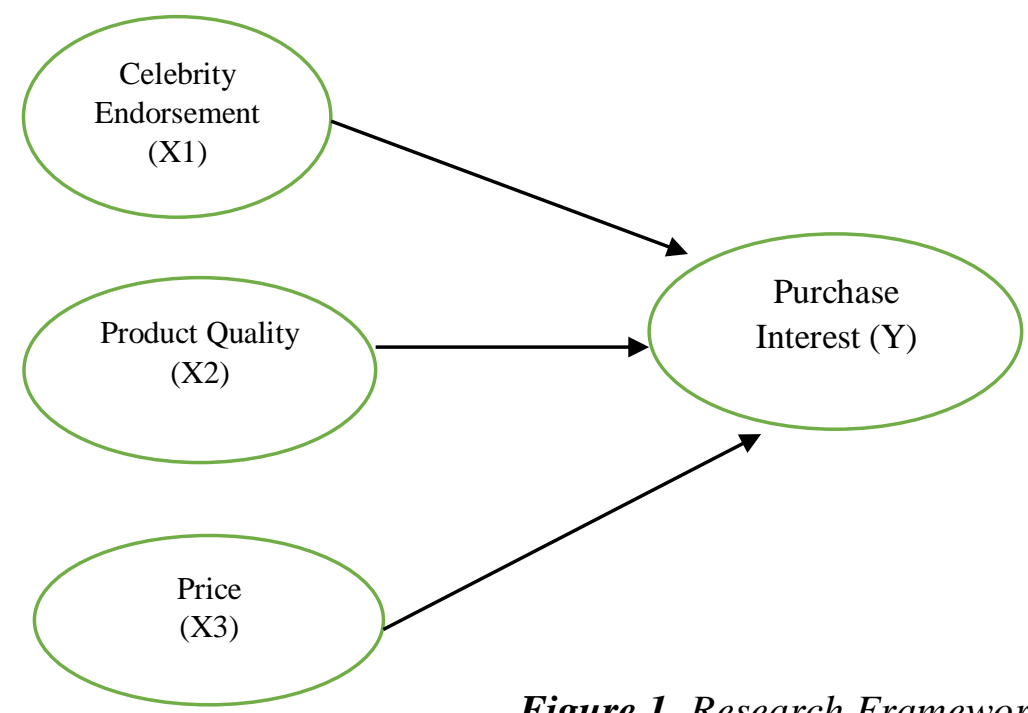

Figure 1. Research Framework

H1: Celebrity Endorsement (X1) affects buying interest (Y)

H2: Product quality (X2) affects purchase intention (Y)

H3: Price (X3) affects buying interest (Y)

\section{Research Methods}

The research method is used in order to select the type of method application appropriate to the research being carried out. The method chosen by the researcher is the descriptive method, Sugiyono (2016), a descriptive research method can be implemented to obtain the presence of independent variables, either in one or more variables (independent variables or independent variables) without comparing the variables themselves and looking for relationships. with other variables. This function is to see if there is a relationship between each variable discussed in the study.

Sugiyono (2016) states that the quantitative research method is said to be a positivistic method because it is based on the philosophy of positivism. This method is considered a scientific method because it fulfills scientific principles, namely concrete / empirical, objective, measurable, rational, and systematic. In the quantitative descriptive method itself is a method used to analyze pre-existing variables in order to strengthen the research results by distributing questionnaires which will later be analyzed by statistical methods to see the results of data in the form of numbers to draw conclusions. With this numerical data, the analysis can be done more easily and quickly.

The data analysis method was carried out using Partial Least Square. This method aims to be used as a reference in assessing data. PLS is a model of SEM or Structural Equation Modeling which is based on a component or variant.

Theory testing is usually done using SEM while PLS is a predictive model. PLS itself is considered to be a powerful analysis. According to Gozali (2006), the use of PLS itself aims to make predictions by conducting several tests such as weight estimates, path estimates, and means.

\subsection{Validiity Test}

This validity test is carried out using several questions as outlined in the questionnaire, namely by calculating the correlation coefficient of each question with the total score obtained then compared with the critical number $\mathrm{r}$ product moment. If the 
correlation coefficient is greater than the critical value, then a question is considered valid. Ghozali (2013: 135).

\subsection{Reliabilitity Test}

Reliability measurement is done by using the one shot method, namely the measurement is only done once, by looking at Croncbach alpha. A construct or variable can be said to be reliable if it gives a cronbach aplha value for each variable more than $60 \%$ or 0.6 , then the research can be said to be reliable Ghozali (2013: 42).

\section{a. Outer Model (Measurement Model)}

The first step taken to get the Outer Model test results is to test the validity. The validity test is considered valid if the instrument can measure the desired data from the research variables accurately and correctly. The validity test is to analyze the confirmatory factors in each latent variable by looking at the convergent validity and discriminant validity calculated by Smart PLS 3.0. Tests carried out on external models:

1. Convergent validity

The value of convergent validity is the value of the loading factor on latent variables with indicators. The expected value is more than 0.5

2. Discriminant Validity

Discriminant Validity is assessed based on cross loading, the construct to be measured and the mean variance extracted (AVE) must be greater than 0.5 .

3. Composite reliability Data that has composite reliability $>0.8$ has high reliability.

4. Average Variance Extracted (AVE)

It is expected that the AVE value is $>0.5$, indicating that it has fulfilled the convergent validity evaluation of Sholihin (2013, p.73).

\section{b. Inner Model (Structural Model)}

The structural model describes the relationship between latent variables based on substantive theory. Some of the tests for structural models are: 1. R Square in endogenous constructs. Rated R Square is the coefficient of determination in endogenous constructs. $\mathrm{R}$ Square values were 0.67 (strong), 0.33 (moderate) and 0.19 (weak). 2. The t test and the significance of the structural path parameter coefficients. The significance value used is the significant level $=10 \% 1.65$, the significant level $=5 \%$ is 1.96 , and the significant level is $1 \%$ 2.58. The significance level value used in this study is a significant level of $5 \%$ with a significant value of 1.96. The steps in the $t$ test are:

1. Formulate a hypothesis

$\mathrm{H} 0: \beta \mathrm{i}=0$, that is, partially the independent variable does not have a significant impact on the dependent variable.

$\mathrm{H} 1: \beta \mathrm{i} \neq 0$, that is, partially the independent variable has a significant impact on the dependent variable.

2. Determine the level of the amount of significance $(\alpha) 0.05$.

3. Make decisions (with significant value)

a) If the $t$ value > from a significant level of $5 \%$ with a significant value of 1.96 , then $\mathrm{H} 0$ is rejected and $\mathrm{H} 1$ is accepted.

b) If the value of $\mathrm{t}$. < from a significant level of $5 \%$ with a significant value of 1.96 , then $\mathrm{H} 0$ is accepted and $\mathrm{H} 1$ is rejected. 


\section{Results and Discussion}

\subsection{Description of the Research Object}

The object for this research is the 2017 FEB Ukrida students by taking data using a questionnaire.

Table 1. Respondent profile

\begin{tabular}{|l|l|l|}
\hline \multicolumn{3}{|c|}{ Respondent profile } \\
\hline Information & total & Percentage \\
\hline Number of & 60 & $100 \%$ \\
samples & & \\
\hline Gender: & & \\
Men & 25 & $42 \%$ \\
Woman & 35 & $58 \%$ \\
\hline Age & $20-30$ & $100 \%$ \\
\hline
\end{tabular}

Based on table 1 above, it can be concluded that the number of female respondents is greater, namely 35 (58\%) compared to male respondents, which amounted to 25 (42\%). All respondents have an age range between 20-30 years.

\section{Descriptive statistics}

Descriptive statistics are carried out in order to analyze the data held and assessed based on the answers of the respondents to the indicators set to measure the variables. For descriptive analysis in this study can be seen in table 2 .

Table 2. Descriptive statistics

\begin{tabular}{|c|c|c|c|c|c|c|}
\hline Variable & N & Minimum & Maximum & Mean & Median & $\begin{array}{c}\text { Standard } \\
\text { Deviation }\end{array}$ \\
\hline $\begin{array}{c}\text { Celebrity } \\
\text { endorsement }\end{array}$ & 60 & 1,00 & 5,00 & 3,99 & 4,00 & 0,902 \\
\hline $\begin{array}{c}\text { Product } \\
\text { Quality }\end{array}$ & 60 & 2,40 & 5,00 & 4,05 & 4,00 & 0,782 \\
\hline Price & 60 & 1,80 & 5,00 & 4,71 & 4,00 & 1,01 \\
\hline $\begin{array}{c}\text { Purchase } \\
\text { Interest }\end{array}$ & 60 & 1,00 & 5,00 & 3,04 & 4,00 & 0,784 \\
\hline
\end{tabular}

Source: Primary data processed, 2021

Based on the data in table 2, it can be shown that the celebrity endorsement variable has a minimum value of 1,00 with an average value of 3,99 and a standard deviation of 
0,902. The average value of 3,99 shows that the average respondent gives an answer "agree" on the statement for the variable indicator Celebrity Endorsement.

The product quality variable has a minimum value of 2,40 with an average value of 4,05 and a standard deviation of 0,782 . The average value of 4.05 shows that the average respondent gives an answer "agree" to the statement for the variable product quality indicator.

The price variable has a minimum value of 1,80 with an average value of 4,71 and a standard deviation of 1,01 . The average value of 4,71 shows that the average respondent gives an answer "agree" on the statement for the price variable indicator.

The product quality variable has a minimum value of 1,00 with an average value of 3,04 and a standard deviation of 0,784 . The average value of 3,04 shows that the average respondent gives a "neutral" answer to the statement for the purchase interest variable indicator.

\subsection{Testing of Data Quality}

Data analysis in this research is by utilizing Structural Equation Modeling (SEM) with Smart PLS, where in testing, according to Gozali, there are two stages, namely the outer model and the inner model which aims to determine the Fit model of the research carried out.

\section{a. Validiity Test}

The validity test was carried out to see how much influence the Celebrity Endorsement variable, product quality, and price would have on purchase intention by utilizing PLS with a sample of 60 respondents.Figure 2 Alogritma PLS testing

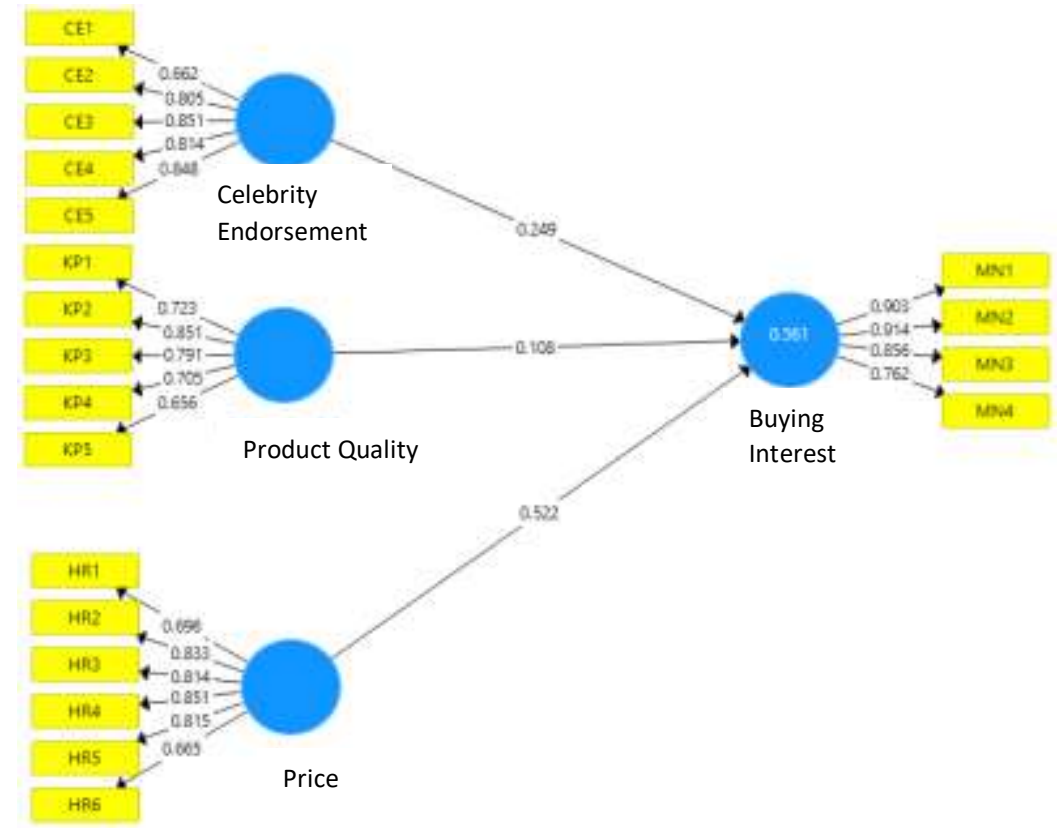

Figure 2. Smart PLS alogritma output

\section{b. Outer Model Measurement}

The outer model serves to explain the relationship between the variables to be tested and the indicators. In using Smart PLS, there are 3 measurement criteria for Convergent Validity, Discriminant Validity and Composite Reliability. 


\section{Convergent Validity Test}

According to Gozali (2006), if the resulting loading value ranges from 0,5 to 0,6 , it is still considered adequate, so in this study the researchers decided that the loading factor limit was 0,6.still considered adequate, so in this study the researchers decided that the loading factor limit was 0,6 .

Table 3. Outer Loadings

\begin{tabular}{|c|c|c|c|}
\hline Variable & Indicator & Loadings & Information \\
\hline \multirow{5}{*}{$\begin{array}{c}\text { Celebrity } \\
\text { Endorsement }\end{array}$} & CE1 & 0,662 & Valid \\
\hline & CE2 & 0,805 & Valid \\
\hline & CE3 & 0,851 & Valid \\
\hline & CE4 & 0,814 & Valid \\
\hline & CE5 & 0,848 & Valid \\
\hline \multirow[t]{5}{*}{ Product Quality } & KP1 & 0,723 & Valid \\
\hline & KP2 & 0,851 & Valid \\
\hline & KP3 & 0,791 & Valid \\
\hline & KP4 & 0,705 & Valid \\
\hline & KP5 & 0,656 & Valid \\
\hline \multirow[t]{6}{*}{ Price } & HR1 & 0,696 & Valid \\
\hline & HR2 & 0,833 & Valid \\
\hline & HR3 & 0,814 & Valid \\
\hline & HR4 & 0,851 & Valid \\
\hline & HR5 & 0,815 & Valid \\
\hline & HR6 & 0,665 & Valid \\
\hline \multirow[t]{4}{*}{ Purchase Interest } & MN1 & 0,903 & Valid \\
\hline & MN2 & 0,914 & Valid \\
\hline & MN3 & 0,856 & Valid \\
\hline & MN4 & 0,762 & Valid \\
\hline
\end{tabular}

Source: Data processing using smart PLS, 2021

As can be seen in table 3, the outer loading results are considered sufficient to meet the convergent validity so that the researcher does not make further modifications to the indicator.

\section{Discriminant Validity Test}

Discriminant validity serves to ensure that a concept on a variable is different from other variables. In this case, a variable is considered to have good discriminant validity when the results of the indicator are greater than the indicators owned by other variables. 
Table 4. Value of Discriminant Validity

\begin{tabular}{|l|l|l|l|l|}
\hline & CE & KP & HR & MN \\
\hline CE1 & 0,662 & 0,310 & 0,238 & 0,319 \\
\hline CE2 & 0,805 & 0,489 & 0,357 & 0,346 \\
\hline CE3 & 0,081 & 0,540 & 0,338 & 0,403 \\
\hline CE4 & 0,814 & 0,415 & 0,435 & 0,566 \\
\hline CE5 & 0,848 & 0,495 & 0,359 & 0,449 \\
\hline KP1 & 0,509 & 0,723 & 0,298 & 0,396 \\
\hline KP2 & 0,424 & 0,851 & 0,472 & 0,423 \\
\hline KP3 & 0,326 & 0,791 & 0,540 & 0,438 \\
\hline KP4 & 0,333 & 0,705 & 0,553 & 0,378 \\
\hline KP5 & 0,497 & 0,656 & 0,432 & 0,472 \\
\hline HR1 & 0,385 & 0,520 & 0,696 & 0,426 \\
\hline HR2 & 0,424 & 0,740 & 0,833 & 0,608 \\
\hline HR3 & 0,284 & 0,480 & 0,814 & 0,625 \\
\hline HR4 & 0,257 & 0,457 & 0,851 & 0,521 \\
\hline HR5 & 0,208 & 0,321 & 0,815 & 0,580 \\
\hline HR6 & 0,577 & 0,365 & 0,665 & 0,478 \\
\hline MN1 & 0,393 & 0,479 & 0,629 & 0,903 \\
\hline MN2 & 0,354 & 0,497 & 0,653 & 0,914 \\
\hline MN3 & 0,376 & 0,473 & 0,618 & 0,856 \\
\hline MN4 & 0,724 & 0,505 & 0,501 & 0,762 \\
\hline & & & &
\end{tabular}

Source: Data processing using smart PLS, 2021

Table 4 is sufficient to explain that the loading factor value possessed by each indicator is still comparable or greater than other latent variables. This means that each variable tested has good discriminant validity where each indicator has a higher correlation with the latent variable.

\section{Reliability Test}

Sugiyono (2015: 184) states that a criterion in making decisions to determine whether or not it is reliable is if $\mathrm{r}$ is greater or equal to 0,600 then the item is reliable. If $\mathrm{r}$ is less than 0,600 then the item is not reliable. Table 6. Cornbach's Alpha 1.

Table 5. Cornbach's Alpha 1

\begin{tabular}{|l|l|}
\hline \multicolumn{1}{|c|}{ Variable } & Cronbach's Alpha \\
\hline Celebrity Endorsement & 0,858 \\
\hline Price & 0,871 \\
\hline Product Quality & 0,800 \\
\hline Purchase Interest & 0,881 \\
\hline
\end{tabular}

Source: Data processing using smart PLS, 2021 
From the data table 6 . shows that the alpha coefficient for each variable is greater than 0,6 , therefore it can be declared reliable and can be continued for the basic research material.

\section{Average Variance Extracted (AVE)}

At the expected AVE value> 0,5 so that it can be said to pass the requirements to meet the convergent validity evaluation.

Table 6. AVE Value (Average Variance Expected)

\begin{tabular}{|l|l|}
\hline \multicolumn{1}{|c|}{ Variable } & Average Variance Expected \\
\hline Celebrity Endorsement & 0,638 \\
\hline Price & 0,612 \\
\hline Product Quality & 0,560 \\
\hline Purchase Interest & 0,741 \\
\hline
\end{tabular}

Source: Data processing using smart PLS, 2021

From the table above, it can be concluded that the AVE value has met the validity of the convergence because the results are above 0,5 for each variable

\section{c. Evaluation of Goodness Of Inner Model}

The function of evaluating the Goodness of Inner Model is to see the amount of ability possessed by endogenous variables to explain how diverse exogenous variables are. The results of the Goodness of Inner Model through R-squares in this study are shown in the table below.

Table 7. R-Square

\begin{tabular}{|c|c|}
\hline Variable & R-Square \\
\hline Purchase Interest & 0,561 \\
\hline
\end{tabular}

Based on the results of R-squares which have a value of 0.561 or $56 \%$, it shows that the diversity possessed by the celebrity endorsement variable, product quality, and price affects purchase interest by $56 \%$. The remaining $44 \%$ is influenced by other variables outside of this study. This also shows that the influence given by the three variables is sufficient to influence the purchase interest variable.

\section{d. Hypothesis Testing}

Hypothesis testing is a stage that is carried out in order to determine the causality that will be developed in the model, namely the effect of exogenous variables on endogenous variables. 


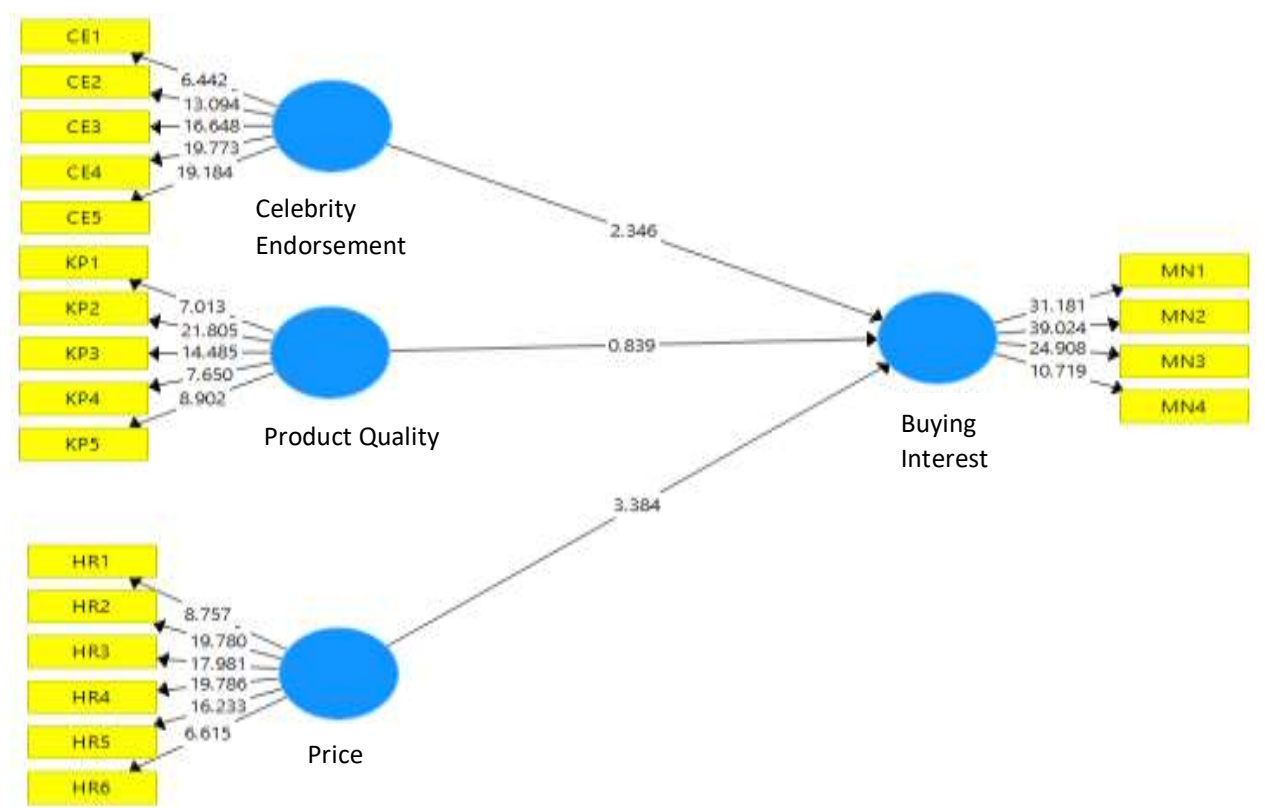

Figure 3. Boostrapping

Table 9. Result for Inner weightsTweights

\begin{tabular}{|l|c|c|c|c|c|}
\hline & Original sample & Sample mean & Standart deviation & T-statistic & P-value \\
\hline Celebrity Endorsement & 0,249 & 0,246 & 0,102 & 2,447 & 0,015 \\
\hline Product Quality & 0,108 & 0,132 & 0,125 & 0,862 & 0,389 \\
\hline Price & 0,522 & 0,519 & 0,148 & 3,535 & 0,000 \\
\hline
\end{tabular}

\subsection{Discussion}

a. The Effect of the Celebrity Endorsement Variable on the Purchase Interest Variable

Celebrity endorsement according to Dinggon, et. al (2015) in his research, is a celebrity action to support the introduction or endorsement of a product that can attract the attention of the audience. The presence of celebrity endorsement at this time has been widely recognized by its existence supported by the high use of the internet today.

Based on the test results, the T-statistic value for the celebrity endorsement variable is 2.447 where $>1.96$ it is concluded that the celebrity endorsement variable has an effect on the purchase interest variable.

The results that appear are similar to the research conducted by Rachmat et.al (2019) entitled "Product Differentiation, Celebrity Endorsement and Purchase Intention: Case Study of Makuta Cake Bandung, West Java, Indonesia". The result shows that Celebrity endorsement has a significant effect on buying interest.

\section{b. The Influence of Product Quality Variables on Purchase Interest Variables}

Product quality, as explained by Kotler (2007) in Fernando, F., \& Aksari, A. (2018) product quality is the characteristics and characteristics of a good or service that affects its ability to satisfy stated or implied needs. .

Judging from the test results that the t-statistic value on the product quality variable is equal to $0.862<1.96$, the conclusion is that the product quality variable has no effect on the purchase intention variable. 
These results are similar to the research from Halim and Iskandar (2019) in their research entitled "The effect of product quality, price and competition on purchase intention". With the result that all the variables chosen to be studied are proven to have no significant effect on consumer purchase interest.

\section{c. The Effect of the Price Variable on the Purchase Interest Variable}

Price as described by Armstrong and Kotler (2012) states that price is an amount of money "sacrificed" for a product or service, consumer value in an effort to benefit from ownership or use of the product or service.

Based on the test results, the T-statistic value for the celebrity endorsement variable is 3.535 where $>1.96$, it is concluded that the celebrity endorsement variable has an effect on the purchase interest variable.

The results that appear are in line with research from Febrian (2019) in his research entitled "The effect of product quality and price on buying interest in batik overtime". The results showed that the variables on product quality and price had a significant effect on the interest in buying batik overtime.

\section{Conclusion}

As explained in the discussion section, the conclusions that can be drawn in this research are:

1. The variable celebrity endorsement as (X1) affects the purchase interest variable (Y) single Kanzler sausage product. Supported by the results of data output managed by Smart PLS, the hypothesis which says that celebrity endorsement has an effect on buying interest in Kanzler sausage products can be accepted. This shows that the existence of celebrity endorsement is able to increase consumer buying interest and this can be utilized properly. The effect is that when someone sees endosers through TikTok media, there will be more possibilities for product purchases due to increased buying interest.

2. The product quality variable as (X2) has no effect on the purchase intention variable (Y) single Kanzler sausage product. Supported by the results of the data output managed by Smart PLS, the hypothesis that product quality affects the buying interest in Kanzler sausage products is not accepted. This may happen because at the present time, it is likely that consumers will pay more attention to how promotions are delivered at an appropriate price. The influence given may not have too much impact, but this does not mean that the company cannot maximize the quality of its products, but if the media used is TikTok, perhaps marketing techniques should be developed.

3. The price variable as (X3) affects the purchase intention variable (Y) for single Kanzler sausage products. Supported by the results of the data output that the price is managed by Smart PLS, the hypothesis that price has an effect on buying interest in Kanzler sausage products can be accepted. This shows that price is an important component to consider in buying a product, therefore sellers must be more careful in setting prices. The effect that can be seen is that the more appropriate the price, the higher the likelihood of a purchase, this shows that the company should pay more attention to price changes that occur on several social media platforms, especially TikTok. 


\section{Suggestions:}

1. For readers of this study, it is primarily targeted at product sellers during the Covid-19 pandemic. It should be noted that based on this research, the variable celebrity endorsement and price are two variables that need special attention. The use of social media such as TikTok if managed properly is likely to increase sales of a product. This is supported by the increase in internet users today. Pricing must also be in accordance with competitor prices, although product quality does not affect the emergence of buying interest, this must also be continuously developed so that in the future, consumer buying interest will increase, and product sales can be carried out properly.

2. For researchers who will research similar matters, it is hoped that they will conduct research with a wider sample so that the data obtained is more representative of the many groups and adds some additional variables to clarify the results of previous research and also add knowledge for other researchers.

\section{References}

Amitay, Y., Tj, H. W., \& Wahyoedi, S. (2020). The Impact of Celebgram Endorsement on Purchase Intention: The Mediating Effects of Customer Attitude and Brand Awareness. Advances in Economics, Business and Management Research, 145(Icebm 2019), 478-484.

Christina, S 2003, 'Celebrities impact on branding. Center on Global Brand Leadership', Journal of Consumers Research, vol.168, no. 8, pp. 54.

Dinggon, M. R., B. Lumanauw, dan I. Trang. 2015. Pengaruh Bauran Pemasaran, Celebrity Endorsment Dan Gaya Hidup Terhadap Keputusan Pembelian Smartphone Samsung Galaxy Pada Mahasiswa Feb Unsrat Manado. Jurnal Emba. 3(3): 1370-1382.

Hasanah, kurniawati . 2017. Effect of Celebrity Endorsement and Word of Mouth of the Decision of the National Film Watching, vol. 12, no.1.

Halim, N. R., \& Iskandar, D. A. (2019). Pengaruh Kualitas Produk, Harga dan Persaingan terhadap Minat Beli. Jurnal Riset Manajemen Dan Bisnis, 4(3), 415-424.

Jeerasantikul, Y., \& Liao, C. (2018). Factors Affecting Chinese Consumers' Willingness to Repurchase Thai Products. BU Academic Review, 17(1), 1-17.

Kotler P, dan G. Armstrong. 2008. Prinsip - Prinsip Pemasaran. Edisi 12, Jilid 1. Erlangga, Jakarta.

Kotler, P., \& Keller, K. L. (2012). Marketing Management. New Jersey: Pearson Education.

Mubarok, D. A. A. (2016). Pengaruh Celebrity Endorsement Terhadap Minat Beli Konsumen (Studi Pada Konsumen Mahasiswa Kelas Reguler Sore STIE INABA Bandung). Jurnal Indonesia Membangun, 3(1), 61-76.

Nelson, O., \& Gloria, O. T. (2012). The Dysfunctional and Functional Effect of Celebrity Endorsement on Brand Patronage. Online Journal of Communication and Media Technologies .

Listyawati, I. H. (2016). Peran Penting Promosi dan Desain Produk Dalam Membangun Minat Beli Konsumen. Jbma, III(Maret), 62-70.

OGUNSIJI, A. S. (2012). The Impact of Celebrity Endorsement on Strategic Brand Management. International Journal of Business and Social Science

Razak (2016) Pengaruh promosi dan harga terhadap minat beli pelanggan Indihome di propinsi DKI Jakarta . Vol. 4. No. 2 Mei 2016. 
Soesatyo, N dan L. J. Rumambi. 2013. Analisa Credibility Celebrity Endorser Model : Sikap Audience Terhadap Iklan Dan Merek Serta Pengaruhnya Pada Minat Beli Top Coffee. Jurnal Manajemen Pemasaran. 1(2): 1-12.

Sudirjo, F. (2018). Pengaruh Kualitas Produk Dan Iklan Terhadap Minat Beli Konsumen AMDK Amidis Di Semarang. E-Jurnal Serat Acitya, 7(1), 910-917.

Sumarwan, Ujang. (2003). Perilaku Konsumen, Teori dan Penerapannya. Jakarta : PT Ghalia Indonesia.

Sugiyono (2015). Metode Penelitian Kombinasi (Mix Methods). Bandung: Alfabeta.

Tj, H. W. (2020). Pengaruh Kualitas Produk dan Harga Terhadap Keputusan Pembelian Minuman Bobba yang Dimediasi dengan Strategi Promosi . Jurnal Ilmiah Indonesia. Vol. 5, No. 12.

Tj, H. W. (2013).Pengaruh Citra,Harga, dan Kepuasan Pelanggan terhadap Loyalitas Pelanggan (Studi Kasus Pada Produk Electro Voice). Vol. 7 No 2 Januari 2013.

Wibowo, M. H., \& Tj, H.W. (2012). Pengaruh Produk Harga Tempat dan Promosi terhadap Kepuasan Konsumen (Studi kasus pada PT Indojaya Multitama). In Jurnal Manajemen Bisnis Kompetensi (Vol. 7, Issue 1, pp. 65-85).

Wirayanthy ,N., \& Santoso. Pengaruh Harga, Citra Merek Dan Kualitas Terhadap Minat Beli Produk Private Label . JMD: Jurnal Riset Manajemen \& Bisnis Dewantara, Vol 2 No 1, Januari 2019. 